\title{
HUBUNGAN USIA, PARITAS, RIWAYAT HIPERTENSI DAN FREKUENSI PEMERIKSAAN ANC TERHADAP KEJADIAN PREEKLAMPSIA PADA IBU HAMIL
}

\author{
Eka Fuazia Laila*) \\ 'Dosen Prodi D III Kebidanan STIKes Sukabumi \\ Email: fauzialailaeka@gmail.com
}

\begin{abstract}
Background : Who mentioned the cause of maternal mortality include: bleeding $28 \%, 13 \%$, eklampsia $10 \%$ of infections, abortion 11\%, 9\%, old partus and causes of lainnya15\% (WHO, 2007). In The RSUD. Palabuhan Ratu own maternal mortality by the year 2015 there is the $21 / 3234$ live births and $42.8 \%$ of the deaths due to preeklampsia. The cause of the preeklampsia is not yet known for sure until now according to Duckitt and Harrington (2005) risk factors for preeklampsia include parity antenatal examinations, jobs, history of hypertension

Purpose: Knowing that correlation of age, parity, a history of hypertension and the frequency of antenatal care checkups with the incidence of preeclampsia in pregnant women.

Methods: Preeklampsia is a special condition in pregnancy, characterized by increased blood pressure and proteinuria. This research is descriptive research using this type of correlation with cross sectional approach using methods, respondents in this research totalled 45 respondents, data analysis by chi square.

Results: Showed heavy $57.8 \%$ experienced preeklampsia, $60 \%$ of respondents were at the age 20-35 years, $57.8 \%$ are a multipara, $51.1 \%$ of the respondents have a history of hypertension and irregular $46.7 \%$ in doing the ANC. test chi square showed no relationship between age, parity, a history of hypertension and the frequency of antenatal care checkups with the incidence of preeclampsia in pregnant women in the space Paus RSUD Palabuhan Ratu with P-value 0.00-0.01<0.05

Conclusion It is expected that mothers who have had their risk factors so that routine pregnancy so that preeklampsia can be checked in early detection of which in the end number preeklampsia can be reduced and for the awarding of the care to be more alacrity in dealing with patients experiencing preeklampsia let alone patients with risk factors for preeklampsia
\end{abstract}

Keywords: Preeclampsia, age, parity, hypertension, ANC

\section{ABSTRAK}

Latar Bekakang:WHO menyebutkan penyebab angka kematian ibu (AKI) diantaranya: perdarahan $28 \%$, eklampsia 13\%, infeksi 10\%, aborsi 11\%, partus lama 9\%, dan penyebab lainnya15\% (WHO, 2007). Di RSUD. Palabuhan Ratu sendiri angka kematian ibu pada tahun 2015 terdapat 21/3234 Kelahiran hidup (KH) dan 42,8\% kematian tersebut akibat preeklampsia. Penyebab preeklampsia belum diketahui secara pasti sampai sekarang menurut Duckitt dan Harrington (2005) faktor resiko preeklampsia meliputi paritas, pekerjaan, pemeriksaan antenatal, dan riwayat hipertensi.

Tujuan:Mengetahui hubungan usia, paritas, riwayat hipertensi dan frekuensi pemeriksaan antenatal care dengan kejadian preeclampsia pada ibu hamil.

Metode Preeklampsia adalah kondisi khusus dalam kehamilan, ditandai dengan peningkatan tekanan darah dan proteinuria. penelitian ini menggunakan jenis penelitian deskriptif korelasi dengan metode pendekatan menggunakan cross sectional, responden dalam penelitian ini berjumlah 45 responden, analisis data dengan chi square.

Hasil: Sebanyak $57,8 \%$ responden mengalami preeklampsia berat, $60 \%$ responden berada pada usia 20 35 tahun, $57,8 \%$ adalah multipara, $51,1 \%$ responden memiliki riwayat hipertensi sebelumnya dan $46,7 \%$ tidak teratur dalam melakukan ANC. Hasil uji chi square menunjukan ada hubungan antara usia, paritas, riwayat hipertensi dan frekuensi pemeriksaan antenatal care dengan kejadian preeclampsia pada ibu hamil di Ruang Paus RSUD dengan P-value 0,00-0,01<0,05 
Kesimpulan: ibu yang mempunyai faktor resiko agar rutin memeriksakan kehamilan sehingga preeklampsia dapat di deteksi secara dini yang pada akhirnya angka preeklampsia dapat berkurang dan bagi para pemberian asuhan agar lebih sigap dalam menangani pasien yang mengalami preeklampsia apalagi pasien dengan faktor resiko preeclampsia

Kata kunci: Preeklamsia, usia, paritas, Hipertensi, ANC

\section{PENDAHULUAN}

Angka Kematian Perinatal (AKP) merupakan parameter yang lebih baik dan lebih peka untuk menilai kualitas pelayanan kesehatan khususnya di bidang maternitas. Hal ini mengingat kesehatan dan keselamatan janin dalam rahim sangat tergantung pada keadaan serta kesempurnaan bekerjanya sistem dalam tubuh ibu, yang mempunyai fungsi untuk menumbuhkan hasil konsepsi dari mudigahmenjadi janin cukup bulan. Salah satu penyebab kematian perinatal adalahpreeklampsia (Sudhaberata,2004).

Kematian ibu memang menjadi perhatian dunia internasional.World Health Organitation (WHO) memperkirakan 529.000 perempuan meninggal tiap tahunnya oleh sebab-sebab kehamilan, dimana kejadian komplikasi kehamilan mencakup $75 \%$ - $80 \%$ dari keseluruhan maternal dengan angka kejadian preeklampsia di dunia sebesar $0-13 \%$. Dan $99 \%$ dari kematian ini terjadi di negara berkembang (Ridwan, 2008). Menurut Survey Demografi Kesehatan Indonesia (SDKI), sepanjang periode 2007-2012 kasus kematian ibu melonjak cukup tajam. Pada tahun 2012, AKI mencapai 359 per 100 ribu penduduk atau meningkat sekitar 57 persen bila dibandingkan dengan kondisi pada 2007, yang hanya sebesar 228 per 100 ribu penduduk. Data ini menyebutkan penyebab angka kematian ibu (AKI) diantaranya: perdarahan $28 \%$, eklampsia $13 \%$, infeksi $10 \%$, aborsi $11 \%$, partus lama $9 \%$, dan penyebab lainnya15\% (WHO, 2007). Di RSUD. Palabuhan Ratu sendiri angka kematian ibu pada tahun 2015 terdapat 21/3234 Kelahiran hidup (KH) dan 42,8\% kematian tersebut akibat preeklampsia (Laporan tahunan Data kematian RSUD. Palabuhan Ratu Tahun 2015)

Preeklampsia adalah kumpulan gejala yang timbul pada ibu hamil, bersalin dan dalam masa nifas yang terdiri dari: hipertensi, dan proteinuria Penyebab preeklampsia belum diketahui sampai sekarang secara pasti, penyakit ini lebih sering ditemukan pada wanita hamil yang primigravida, hiperplasentosis, mempunyai dasar penyakit vaskular, mempunyai riwayat preeklampsia dalam keluarganya (Sastrawinata, 2003).Akan tetapi untuk mendeteksi preeklampsia sedini mungkin yaitu dengan melalui pemeriksaan antenatal secara teratur mulai dari trimester I sampai dengan trimester III dalam upaya mencegah preeklampsia menjadi lebih berat (Manuaba, 2008).

Hasil penelitian Bahari (2009), di Rumah Sakit Umum Daerah dr. Soetomo Surabaya mendapatkan hasil bahwa kejadian preeklampsia pada ibu bersalin sebagian besar dialami oleh ibu bersalin dengan usia $<20$ tahun, lebih dari setengah kejadian preeklampsia pada ibu bersalin terjadi pada ibu primipara, dan ada hubungan usia dan paritas terhadap kejadian preeklampsia pada ibu bersalin. (www.ejournal.litbang.depkes.go.id/ di akses tanggal 01 Januari 2016)

Penelitian Bakti Utami (2008 di RSUP Dr. Soeradji Tirtonegoro Klaten di dapatkan hasil uji Chi-Square menunjukkan bahwa terdapat hubungan antara umur, gravida, riwayat preeklampsia dan riwayat hipertensi dengan kejadian preeklampsia. Besarnya risiko untuk umur OR=19,800 (95\% Cl OR=4,297-91,245), gravida $\mathrm{OR}=3,308 \quad(95 \% \mathrm{Cl} \quad \mathrm{OR}=1,269-8,624)$, riwayat preeklampsia OR=17,588 $(95 \% \quad \mathrm{Cl} \quad \mathrm{OR}=2,194$ 141,023), riwayat hipertensi $\mathrm{OR}=7,295(95 \%$ CIOR=2,245-23,706)(http://www.fkm.undip.ac.id/ di akses tanggal 01 Juni 2014

Penelitian Dinda Nova Hermawan, dkk (2013) Di Puskesmas Buaran Kabupaten Pekalongan menunjukan ada hubungan yang signifikan antara keteraturan antenatal care dengan resiko kejadian preeklampsia pada ibu hamil di Puskesmas Buaran Kabupaten Pekalongan, didapatkan $p$ value 0,025 ( $p$ value $<0,05$ ) dan didapatkan nilai $O R$ sebesar 14,700 yang artinya bahwa ibu hamil yang melakukan antenatal care secara tidak teratur berpeluang 14,700 kali beresiko preeklampsiadibandingkan dengan ibu hamil yang melakukan antenatal care secara teratur(http://www.e-skripsi.stikesmuh-pkj.ac.id/ di akses tanggal 10 Januari 2016

Salah satu upaya untuk menurunkan Angka Kematian Perinatal (AKP) akibat preeklampsia adalah dengan menurunkan angka kejadian preeclampsia. Angka kejadian dapat diturunkan melalui upaya pencegahan, pengamatan dini, dan terapi.Upaya pencegahan kematian perinatal dapat diturunkan bila dapat diidentifikasi faktor-faktor yang 
mempunyai nilai prediksi.Saat ini beberapa faktor resiko telah berhasil diidentifikasi, sehingga diharapkan dapat mencegah timbulnya preeklampsia. Menurut Duckitt dan Harrington (2005) faktor resiko preeklampsia meliputi paritas, pekerjaan, pemeriksaan antenatal, dan riwayat hipertensi

Berdasarkan fenomena tersebut penulis termotivasi untuk membahas lebih lanjut melalui penelitian dengan judul "Hubungan Usia, Paritas, Riwayat Hipertensi Dan Frekuensi Pemeriksaan Antenatal Care Dengan Kejadian Preeklampsia Pada Ibu Hamil di Ruang Paus RSUD. Palabuhan Ratu Kabupaten Sukabumi"

\section{METODOLOGI PENELITIAN}

Penelitian ini menggunakan jenis penelitian deskriptif korelasi dengan pendekatan pada penelitian ini menggunakan cross sectional, yaitu dimana keseluruhan data, baik yang merupakan variabel independen dan dependen dikumpulkan dalam waktu yang bersamaan, Populasi dalam penelitian ini adalah seluruh ibu hamil yang dirawat di Ruang Paus RSUD. Palabuhan Ratu Kabupaten Sukabumi dengan diagnosa medis preeklampsia, pada bulan Februari-Juli 2016, dan Sampel dalam penelitian ini berjumlah 45 responden atau pasien. Teknik pengambilan sampel yang digunakan dalam penelitian ini adalah purposive sampling dengan kriteria inklusi dalam penelitian ini adalah: 1) Responden dengan diagnosa medis preeklampsi tanpa komplikasi, 2) Responden dengan kesadaran compos mentis, 3) responden yang kooperatif dengan usia kehamilan trimester III. dan kriteria eksklusi dalam penelitian ini adalah: 1) Responden yang tidak bersedia diteliti dan tidak menandatangani informed consent., 2) Responden tidak kooferatif, 3) Responden yang kondisinya memburuk ketika penelitian dilakukan

Instrumen pada penelitian ini adalah menggunakan kuesioner dengan pertanyaan tertutup, Data yang terkumpuldilakukananalisismenggunakan bantuan program SPSS for windows versi 16.0. Analisis data yang digunakan adalah analisis univariabel dan bivariabel,analisis data bivariabel menggunakan Chi-square

HASIL

Berdasarkan pengumpulan dan pengolahan data yang telah dilakukan, maka hasil penelitian ini dapat diuraikan sebagai berikut:

Tabel 1 Gambaran usia, paritas, riwayat penyakit hipertensi,dan frekuensi pemeriksaan antenatal care ibu hamil di Ruang Paus RSUD. Palabuhan Ratu Kabupaten Sukabumi

\begin{tabular}{|c|c|c|}
\hline \multirow{2}{*}{\multicolumn{3}{|c|}{$\begin{array}{ll} & \text { Variabel } \\
\text { Usia }\end{array}$}} \\
\hline & & \\
\hline Beresiko & 18 & 40 \\
\hline Tidak Beresiko & 27 & 60 \\
\hline Total & 45 & 100 \\
\hline \multicolumn{3}{|l|}{ Paritas } \\
\hline tMultipara & 26 & 57,8 \\
\hline Primipara & 19 & 42,2 \\
\hline Total & 45 & 100 \\
\hline \multicolumn{3}{|l|}{ Riwayat Hipertensi } \\
\hline $\mathrm{Ya}$ & 23 & 51,1 \\
\hline Tidak & 22 & 48,9 \\
\hline Total & 45 & 100 \\
\hline \multicolumn{3}{|l|}{ Pemeriksaan ANC } \\
\hline Teratur & 24 & 53,3 \\
\hline Tidak Teratur & 21 & 46,7 \\
\hline Total & 45 & 100 \\
\hline
\end{tabular}

Dari Tabel 1 menunjukan bahwa dari 45 responden, $18(40 \%)$ berada pada usia beresiko yaitu $<20$ tahun atau $>35$ tahun, 66 responden $(57,8 \%)$ merupakan multipara, 23 responden
(51,1\%) mempunyai riwayat hipertensi dan 21 responden $(46,7 \%)$ tidak teratur dalam pemeriksaan ANC. 
Tabel 2 Gambaran kejadian preeklamsia di Ruang Paus RSUD. Palabuhan Ratu Kabupaten Sukabumi

\begin{tabular}{lcc}
\hline \multicolumn{1}{c}{ Variabel } & Frekuensi $(\mathrm{f})$ & Presentasi $(\%)$ \\
\hline Preeklampsia & & \\
Ringan & 19 & 42,2 \\
Berat & 26 & 57,8 \\
\hline \multicolumn{1}{c}{ Total } & 45 & 100 \\
\hline
\end{tabular}

Dari Tabel 2 menunjukan dari 45 responden sebagian besar mengalami preeklampsia berat yaitu 26 responden $(57,8 \%)$ dan sisanya mengalami preeklampsia ringan yaitu 19 responden $(42,2 \%)$.

Tabel 3 Hubungan usia ibu dengan kejadian preeklampsia di Ruang Paus RSUD. Palabuhan Ratu Kabupaten Sukabumi

\begin{tabular}{cccccccc}
\hline \multirow{2}{*}{ Usia } & \multicolumn{4}{c}{ Preeklampsia } & \multicolumn{2}{c}{ Jumlah } & \multirow{2}{*}{ P value } \\
\cline { 2 - 7 } & \multicolumn{3}{c}{ Berat } & \multicolumn{2}{c}{ Ringan } & & \\
\cline { 2 - 7 } & $\mathrm{F}$ & $\%$ & $\mathrm{~F}$ & $\%$ & $\mathrm{~F}$ & $\%$ & \\
\hline Beresiko & 13 & 72,2 & 5 & 27,8 & 18 & 100 & \multirow{2}{*}{0,001} \\
\hline Tidak Beresiko & 6 & 22,2 & 21 & 77,8 & 27 & 100 & \\
\hline Jumlah & 19 & & 26 & & 45 & & \\
\hline
\end{tabular}

Berdasarkan Tabel 3 menunjukan ibu yang berusia kategori beresiko sebagian besar mengalami preeklampsia berat yaitu $13(72,2 \%)$, sedangkan ibu yang usianya kategori tidak beresiko sebagian besar mengalami preeklampsia ringan 21 $(77,8 \%)$
Hasil uji statistik analisa bivariat diperoleh $P$ value $=0,001<0,05$ berarti $\mathrm{HO}$ ditolak maka terdapat hubungan antara usia ibu dengan kejadian preeklampsia.

Tabel 4 Hubungan Paritas ibu dengan kejadian preeklampsia di Ruang Paus RSUD. Palabuhan Ratu Kabupaten Sukabumi

\begin{tabular}{cccccccc}
\hline & \multicolumn{4}{c}{ Preeklampsia } & \multicolumn{2}{c}{ Jumlah } & \multirow{2}{*}{ P value } \\
\cline { 2 - 7 } Paritas & \multicolumn{3}{c}{ Berat } & \multicolumn{2}{c}{ Ringan } & & \\
\cline { 2 - 7 } & $\mathrm{F}$ & $\%$ & $\mathrm{~F}$ & $\%$ & $\mathrm{~F}$ & $\%$ & \\
\hline Multipara & 7 & 26,9 & 19 & 73,1 & 26 & 100 & \multirow{2}{*}{0,015} \\
Primipara & 12 & 63,2 & 7 & 36,8 & 19 & 100 & \\
\hline Jumlah & 19 & & 26 & & 45 & & \\
\hline
\end{tabular}

Berdasarkan Tabel 4 menunjukan ibu yang multipara sebagian besar mengalami preeklampsia ringan yaitu 19(73,1\%), sedangkan ibu yangprimipara sebagian besar mengalami preeklampsia berat $12(63,2 \%)$
Hasil uji statistik analisa bivariat diperoleh $P$ value $=0,01<0,05$ berarti $\mathrm{H} 0$ ditolak maka terdapat hubungan antara paritasdengan kejadian preeklampsia.

Tabel 5 Hubungan riwayat hipertensi ibu dengan kejadian preeklampsia di Ruang Paus RSUD. Palabuhan Ratu Kabupaten Sukabumi

\begin{tabular}{ccccccccc}
\hline \multirow{2}{*}{$\begin{array}{c}\text { Riwayat } \\
\text { Hipertensi }\end{array}$} & \multicolumn{4}{c}{ Preeklampsia } & \multicolumn{2}{c}{ Jumlah } & \multirow{2}{*}{ P value } \\
\cline { 2 - 7 } & \multicolumn{3}{c}{ Berat } & \multicolumn{2}{c}{ Ringan } & & \\
\cline { 2 - 7 } & $\mathrm{F}$ & $\%$ & $\mathrm{~F}$ & $\%$ & $\mathrm{~F}$ & $\%$ & \\
\hline Ya & 14 & 60,9 & 9 & 39,1 & 23 & 100 & \multirow{2}{*}{0,01} \\
Tidak & 5 & 22,7 & 17 & 77,3 & 22 & 100 & \\
\hline Jumlah & 19 & & 26 & & 45 & & \\
\hline
\end{tabular}


Berdasarkan Tabel 5 menunjukan ibu yang mempunyai riwayat hipertensi sebelumnyan sebagian besar mengalami preeklampsia berat yaitu $14(60,9 \%)$, sedangkan ibu yang tidak mempunyai riwayat hipertensi sebagian besar mengalami preeklampsia ringan $17(77,3 \%)$
Hasil uji statistik analisa bivariat diperoleh $P$ value $=0,01<0,05$ berarti $\mathrm{H} 0$ ditolak maka terdapat hubungan antara riwayat hipertensi dengan kejadian preeklampsia.

Tabel 6 Hubungan frekuensi pemeriksaan antenatal care ibu dengan kejadian preeklampsia di Ruang Paus RSUD. Palabuhan Ratu Kabupaten Sukabumi

\begin{tabular}{ccccccccc}
\hline \multirow{2}{*}{ ANC } & \multicolumn{4}{c}{ Preeklampsia } & \multicolumn{2}{c}{ Jumlah } & \multirow{2}{*}{ P value } \\
\cline { 2 - 7 } & \multicolumn{3}{c}{ Berat } & \multicolumn{2}{c}{ Ringan } & & \\
\cline { 2 - 7 } & $\mathrm{F}$ & $\%$ & $\mathrm{~F}$ & $\%$ & $\mathrm{~F}$ & $\%$ & \\
\hline Ya & 4 & 16,7 & 20 & 83,3 & 24 & 100 & \multirow{2}{*}{0,000} \\
Tidak & 15 & 71,4 & 6 & 28,6 & 21 & 100 & \\
\hline Jumlah & 19 & & 26 & & 45 & & \\
\hline
\end{tabular}

Berdasarkan Tabel 6 menunjukan ibu yang tidak teratur dalam pemeriksaan ANC sebagian besar mengalami preeklampsia berat yaitu 15 $(71,4 \%)$, sedangkan ibu yang teratur dalam pemeriksaan ANC sebagian besar mengalami preeklampsia ringan $20(83,3 \%)$

Hasil uji statistik analisa bivariat diperoleh $P$ value $=0,000<0,05$ berarti $\mathrm{H} 0$ ditolak maka terdapat hubungan antara frekuensi pemeriksaan ANC dengan kejadian preeklampsia.

\section{PEMBAHASAN}

\section{Univariat}

Umur ibu adalah usia yang dihitung mulai dari tanggal kelahiran hingga ibu dirawat, yang dihitung dalam tahun (Daryanto, 2002). Hasil penelitian menunjukan bahwa sebagian besar responden berada pada usia 20-35 tahun yaitu $60 \%$.Umur merupakan bagian dari status reproduksi yang penting. Umur berkaitan dengan peningkatan atau penurunan fungsi tubuh sehingga mempengaruhi status kesehatan seseorang. Umur yang baik untuk hamil adalah 20-35 tahun (Depkes Rl,2000). Royston and Armstrong (1994) juga menyebutkan bahwa umur 20-35 tahun merupakan umur yang paling aman bagi wanita untuk hamil dan melahirkan. Jadi dapat disimpulkan bahwa hasil penelitian ini menunjukan bahwa sebagian besar responden memiliki umur yang tepat untuk melahirkan.

Paritas adalah jumlah anak yang telah dilahirkan oleh seorang ibu baik lahir hidup maupun lahir mati (Amiruddin, 2004). Hasil penelitian menunjukan bahwa sebagian besar responden adalah multipara yaitu $57,8 \%$, Paritas 2-3 merupakan paritas yang aman ditinjau dari sudut kematian maternal, paritas 1 dan lebih dari 3 mempunyai angka kematian maternal yang tinggi. (Wiknjosastro, 2005). Ini berarti masih ada $42,2 \%$ ibu hamil dalam penelitian ini yang masuk dalam resiko tinggi.

Hasil penelitian menunjukan sebanyak $51,1 \%$ responden memiliki riwayat hipertensi, teori yang dikemukakan Robert dan Redman yang mengatakan Peningkatan resiko preeklampsia dapat terjadi pada ibu yang memiliki riwayat hipertensi kronis. Ini berarti hasil penelitian sesuai dengan teori yang ada bahwa ibu yang memiliki riwayat hipertensi merupakan faktor resiko terjadinya preeklampsia

Pemeriksaan antenatal adalah pemeriksaan kehamilan yang dilakukan untuk memeriksa keadaan ibu dan janin secara berkala yang diikuti dengan upaya koreksi terhadap penyimpangan yang ditemukan (Depkes RI.2008). hasil penelitian menunjukan bahwa sebanyak $53,3 \%$ responden teratur memeriksakan kehamilannya hal ini sesuai dengan teori yang ada yang mengatakan bahwa keteraturan ANC adalah kedisiplinan / kepatuhan ibu hamil untuk melakukan pengawasan sebelum anak lahir terutama ditujukan pada anak.

Preeklampsia ialah penyakit dengan tandatanda hipertensi, edema, dan proteinuria yang timbul karena kehamilan. Penyakit ini umumnya terjadi dalam trimester III kehamilan, tetapi dapat terjadi sebelumnya, misalnya pada molahidatidosa (Hanifa Wiknjosastri, 2007). Hasil penelitian menunjukan dari 45 responden sebagian besar mengalami preeklampsia berat yaitu 26 responden $(57,8 \%)$ dan sisanya mengalami preeklampsia ringan yaitu 19 responden (42,2\%) ini bisa dikarenakan sebagian besar responden memiliki riwayat hipertensi sebelumnya. 


\section{Bivariat}

Hubungan usia ibu dengan kejadian preeklampsia di Ruang Paus RSUD. Palabuhan Ratu Kabupaten Sukabumi

Hasil penelitian menunjukan ibu yang berusia kategori beresiko sebagian besar mengalami preeklampsia berat yaitu $13(72,2 \%)$, sedangkan ibu yang usianya kategori tidak beresiko sebagian besar mengalami preeklampsia ringan 21 $(77,8 \%)$

Hal ini sesuai dengan teori yang dikemukakan Sudhaberata, 2007 yang mengatakan bahwa Distribusi kejadian Preeklampsia berdasarkan umur menurut beberapa referensi banyak ditemukan pada kelompok usia ibu yang ekstrem yaitu kurang dari 20 tahun dan lebih dari 35 tahun dan faktor resiko pada kehamilan Preeklampsia berat menemukan $2 / 3$ kematian maternal terjadi pada usia di atas 30 tahun atau lebih. Hal ini memperkuat penderita bahwa kenaikan tekanan darah pada wanita hamil berusia muda akan lebih menimbulkan kejang. Sedangkan menurut para ahli, semakin meningkatnya umur ibu hamil maka semakin meningkat pula angka kejadian Preeklampsia dalam kehamilan (Sudhaberata, 2007).

Hasil uji statistik analisa bivariat diperoleh $P$ value $=0,001<0,05$ berarti $\mathrm{H} 0$ ditolak maka terdapat hubungan antara usia ibu dengan kejadian preeklampsia ini sesuai dengan penelitian Bahari (2009), di Rumah Sakit Umum Daerah dr. Soetomo Surabaya mendapatkan hasil bahwa kejadian preeklampsia pada ibu bersalin sebagian besar dialami oleh ibu bersalin dengan usia $<20$ tahun dan penelitian Bakti Utami (2008) yang mengatakan ibu hamil yang berusia $<20$ tahun atau $>35$ tahun 19 kali lebih besar mengalami preeklampsia.

Hubungan Paritas ibu dengan kejadian preeklampsia di Ruang Paus RSUD. Palabuhan Ratu Kabupaten Sukabumi

Hasil penelitian menunjukan ibu yang multipara sebagian besar mengalami preeklampsia ringan yaitu $19(73,1 \%)$, sedangkan ibu yang primipara sebagian besar mengalami preeklampsia berat $12(63,2 \%)$. Hal ini sesuai dengan teori Wiknjosastro, 2005 mengatakan bahwa paritas 1 dan lebih dari 3 mempunyai angka kematian maternal yang tinggi. Sedangkan Sibai et al (1995) dan Skjaerven (1995) juga berpendapat bahwa proporsi primigravida lebih tinggi daripada wanita yang pernah hamil sebelumnya.

Hasil uji statistik analisa bivariat diperoleh $P$ value $=0,01<0,05$ berarti $\mathrm{H} 0$ ditolak maka terdapat hubungan antara paritas dengan kejadian preeklampsia ini sesuai dengan penelitian Bahari (2009), di Rumah Sakit Umum Daerah dr. Soetomo Surabaya mendapatkan hasil bahwa lebih dari setengah kejadian preeklampsia pada ibu bersalin terjadi pada ibu primipara, dan ada hubungan usia dan paritas terhadap kejadian preeklampsia pada ibu bersalin.

Hubungan riwayat hipertensi ibu dengan kejadian preeklampsia di Ruang Paus RSUD. Palabuhan Ratu Kabupaten Sukabumi

Hasil penelitian menunjukan ibu yang mempunyai riwayat hipertensi sebelumnya sebagian besar mengalami preeklampsia berat yaitu $14(60,9 \%)$, sedangkan ibu yang tidak mempunyai riwayat hipertensi sebagian besar mengalami preeklampsia ringan 17 (77,3\%). Peningkatan resikopreeklampsia/eklampsia dapat terjadi pada ibu yang memiliki riwayat hipertensi kronis, diabetes, dan adanya riwayat preeklampsia/eklampsia sebelumnya. (Robert \& Redman, 1993). Sedangkan menurut Ben-zion Taber (1994), faktor-faktor predisposisi preeklampsia meliputi: Nullipara umur belasan tahun, Pasien yang miskin dengan pemeriksaan antenatal yang kurang atau tidak sama sekali dan nutrisi yang buruk terutama dengan diet kurang protein, Mempunyai riwayat preeclampsia/eklampsia dalam keluarga, Mempunyai penyakit vascular hipertensi sebelumnya dan Kehamilan-kehamilan dengan trofoblas yang berlebihan ditambah vili korion (Kehamilan ganda, Mola hidatidosa, Diabetes Mellitus, Hidrops fetalis)

Hasil uji statistik analisa bivariat diperoleh $P$ value $=0,01<0,05$ berarti $\mathrm{H} 0$ ditolak maka terdapat hubungan antara riwayat hipertensi dengan kejadian preeklampsia ini sesuai dengan penelitian yang dilakukan Bakti Utami (2008) yang menunjukkan bahwa terdapat hubungan antara umur, gravida, riwayat preeklampsia dan riwayat hipertensi dengan kejadian preeklampsia. Besarnya risiko riwayat hipertensi $\mathrm{OR}=7,295$ artinya ibu yang memiliki riwayat hipertensi memiliki resiko 7 kali lebih besar mengalami preeklampsia dibandingkan dengan ibu yang tidak mempunyai riwayat hipertensi

Hubungan frekuensi pemeriksaan antenatal care ibu dengan kejadian preeklampsia di Ruang Paus RSUD. Palabuhan Ratu Kabupaten Sukabumi

Hasil penelitian menunjukan ibu yang tidak teratur dalam pemeriksaan ANC sebagian besar mengalami preeklampsia berat yaitu $15(71,4 \%)$, sedangkan ibu yang teratur dalam pemeriksaan 
ANC sebagian besar mengalami preeklampsia ringan $20(83,3 \%)$ ini dapat diartikan bahwa semakin sering melakukan pemeriksaan ANC maka resiko terkena preeklampsia semakin kecil sesuai dengan teori yang dikemukakan manuaba untuk mendeteksi preeklampsia sedini mungkin yaitu dengan melalui pemeriksaan antenatal secara teratur mulai dari trimester I sampai dengan trimester III dalam upaya mencegah preeklampsia menjadi lebih berat

Hasil uji statistik analisa bivariat diperoleh $P$ value $=0,000<0,05$ berarti $\mathrm{H} 0$ ditolak maka terdapat hubungan antara frekuensi pemeriksaan ANC dengan kejadian preeklampsia ini sesuai dengan penelitian Dinda Nova Hermawan, dkk (2013) didapatkan bahwa ada hubungan yang signifikan antara keteraturan antenatal care dengan resiko kejadian preeklampsia pada ibu hamil dengan nilai OR sebesar 14,700 yang artinya bahwa ibu hamil yang melakukan antenatal care secara tidak teratur berpeluang 14,700 kali beresiko preeklampsiadibandingkan dengan ibu hamil yang melakukan antenatal care secara teratur

\section{SIMPULAN}

Berdasarkan hasil penelitian dapat disimpulkan $40 \%$ respondenberada pada usia beresiko yaitu $<20$ tahun atau $>35$ tahun, $57,8 \%$ respondenmerupakan multipara, $51,1 \%$ respondenmempunyai riwayat hipertensi dan $46,7 \%$ respondentidak teratur dalam pemeriksaan ANC. Sebagian besar responden mengalami preeklampsia berat yaitu 26 responden $(57,8 \%)$ dan sisanya mengalami preeklampsia ringan yaitu 19 responden $(42,2 \%)$. Ada hubungan antara usia, paritas, riwayat hipertensi, frekuensi pemeriksaan ante natal care dengan kejadian preeklampsia pada ibu hamil di RSUD R Syamsudin SH dengan nilai P value $(0,000-0,001)<0,05$ dengan keeratan hubungan lemah-cukup kuat

\section{SARAN}

Diharapkan agar ibu yang mempunyai faktor resiko agar rutin memeriksakan kehamilan sehingga preeklampsia dapat di deteksi secara dini yang pada akhirnya angka preeklampsia dapat berkurang dan bagi para pemberian asuhan agar lebih sigap dalam menangani pasien yang mengalami preeklampsia apalagi pasien dengan faktor resiko preeklampsia

\section{DAFTAR PUSTAKA}

Amiruddin, R., Kandi, E.P., Ayani, W., Chaerunnisa,A., Ambas, W.A., Afifah, A.(2007). Current Issue Pre Eklampsie
Dan Eklamsi Di Indonesia; BagianEpidemiologi FKM UNHAS Makassar, (Online) diunduh 25 Januari 2012.Available from URL: HYPERLINK

Arikunto, Suharsimi 2010, Manajemen Penelitian, Rineka Cipta, Jakarta.

Billington, M \& Stevenson, M 2010, Kegawatan dalam Kehamilan - Persalinan: Buku Saku Bidan, alih bahasa; Ariani, F \& Widiarti, D, ed Wahyuningsih, E \& Rahayu, YD, EGC, Jakarta.

Bobak, Lowdermik \& Jensen 2005, Buku Ajar Keperawatan Maternitas, alih bahasa; Wijayanti, M, ed Komalasari, edk 4, EGC, Jakarta.

Briley, Annette, 2006, Asuhan Kebidanan Pada Persalinan : Preeklampsia, Penerbit Buku Kedokteran, EGC, Jakarta

Caroline H, 2008. Terapi Preeklampsia, Jurnal Cermin Dunia Kedokteran Vol. 35, Nomer 1, Grup PT Kalbe Farma Tbk, Jakarta.

Chapman, Vicky 2006, Asuhan Kebidanan: Persalinan \& Kelahiran, alih bahasa; Kuncara, Y, ed, Ester, Monica, EGC, Jakarta.

Cuningham, et al. 2005. Obstetri Williams. Edisi 21. Jakarta: EGC

Dahlan, Sopiyudin.M. 2006, Statistik Kedokteran dan Kesehatan, PT.Arkans, Jakarta

Dharma, Kelana Kusuma 2011, Metodologi Penelitian Keperawatan Panduan Melaksanakan dan Menerapkan Hasil Penelitian, CV. Trans Info Media, Jakarta.

Hastono, sp \& Luknis Sasri 2010, Statistik Kesehatan, edk 2, cet 4, PT. Raja Gravindo Perjada, Jakarta.

Hidayat, Alimul Aziz 2009, Metode Penelitian Keperawatan dan Teknik Analisa Data, Salemba Medika, Jakarta.

Hutahean, Serri 2009, Asuhan Keperawatan dalam Maternitas dan GInekologi, CV, Trans Info Medika, Jakarta.

Departemen Kesehatan Indonesia. 2004, Pusat Promosi Kesehatan, KIE safe Motherhood "Making Pregnancy Safer", Depkes RI, Jakarta

Departemen Kesehatan Indonesia. 2007, Profil Kesehatan Indonesia, Depkes RI, Jakarta

Departemen Kesehatan Indonesia. 2007, Survey Demografi Kesehatan Indonesia, Depkes RI, Jakarta

Jurnal kesehatan Indonesia Vo. 1, No 5. April 2007. Tantangan Pencapaian Millenium 
Development Goals (MGDs) Bidang Kesehatan

Jurnal IImiah Universitas Batanghari Jambi 8(2):24Wati, Risthiana, D. (2009). Hubungan Antara Preeklampsia Berat dengan AsfiksiaNeonatorum di RSUD Ponogoro per 1 Januari 2008-31 Desember 2008,(Tesis). Surakarta: Universitas Muhammadiyah Surakarta.

Kelly O, Kim. T., Tell. K., Langer. A. (2007).. Balancing The Scales (ExpandingTreatment for Pregnant Women With Life-Threatening Hypertensive Conditions in Developing Countries. Engerderhealth. (30): 5-8

Klonoff, CHS,et.al. 1989, An Epidemiology Study of Contraception And Preeclampsia, JAMA 262 : 3143-3147

Kusmiyati, Yuni 2010, Penuntun Praktikum Asuhan Kehamilan, Fitramaya, Jakarta.

Laporan tahunan dinas kesehatan Kabupaten sukabumi 2015.

Laporan tahunan RSUD. Palabuhan Ratu Kabupaten Sukabumi

Leisure-Time Physical Activity, and Risk of Preeclampsia and Gestational

Mandriwati, G.A 2012, Asuhan Kebidana Antenatal: Penuntun belajar, edk. 2, EGC, Jakarta.

Manuaba, I.G.B, 2004, Kapita Selekta Penatalaksanaan Rutin Obstetri Ginekologi Dan KB, Penerbit Buku Kedokteran, EGC, Jakarta

Manuaba. I.B.G. 2008. IImu Kebidanan, Penyakit Kandungan, dan Keluarga Berencana untuk Pendidikan bidan. Editor, Seriawan,Ed.I. Jakarta. EGC

Manurung, S, Tutiany \& Suryati 2011, Buku Ajar Maternitas Asuhan Keperawatan Antenatal, CV. Trans Info Media, Jakarta

Meilani, Niken, et al 2009, Kebidanan Komunitas, ed Machfoedz, Ircham, Fitramaya, Yogyakarta.

Merviel, P., Touzart, L., Deslandes, V., Delmas, M., Coicaud, M., \& Gondry, J. (2008).Risk factors of preeclampsia in single pregnancy, Journal GynecologyObstetric Biology 37(5):477-82.

Mochtar, Rustam. 2004. Preeklampsia dalam Sinopsis Obstetri. Jakarta. EGC

Moffat, McKay S \& Lee, Pam 2011, Panduan Praktik Mahasiswa Kebidanan, alih bahasa; Yulianti, Devi, ed Tiar, E, EGC, Jakarta.

Mufdlilah 2009, Panduan Asuhan Kebidanan Ibu Hamil, Nuha Medika, Yogjakarta.
Murray, S.S. 2006. Foundations of MaternalNewborn and Women's Health

Notoadmojo, S. 2005. Metodologi Penelitian Kesehatan. Jakarta: Rineka Cipta

Notoadmojo, Soekidjo 2005, Promosi Kesehatan Teori dan Aplikasinya, Rineka Cipta, Jakarta.

Notoatmodjo, Soekidjo, 2010, Metodologi Penelitian Kesehatan, Rineka Cipta, Jakarta

Nursalam 2008, Konsep dan Penerapan Metodologi Penelitian IImu Keperawatan, edk 3, Salemba Medika, Jakarta.

Prawiryohardjo, Sarwono 2009, IImu Kebidanan, edk 4, cet 2, ed Saifuddin, Rachimhadhi \& Wiknjosastro, PT Bina Pustaka Sarwono Prawirohardjo, Jakarta.

Pudiastuti, Ratna Dewi 2012, Asuhan Kebidanan pada Ibu Hamil Normal \& Patologi, Nuha Medika, Yogjakarta.

Roeshadi, R,H 2007, Upaya Menurunkan Angka Kesakitan dan Angka Kematian Ibu pada Penderita Preeklampsia dan Eklampsia, vol 31, no 3, Fakultas Kedokteran Universitas Sumatra Utara, Medan.

Rohmah, Nikmatur 2010, Pendidikan Prenatal Upaya Promosi Kesehatan Bagi Ibu Hamil, Gramata Publishing, Jakarta.

Saifuddin, Abdul Bari 2009, Buku Acuan Nasional Pelayanan Kesehatan Maternal dan Neonatal, edk 1, cet 5, ed Adrianse, Wiknjosastro \& Waspodo, PT. Bina Pustaka Sarwono Prawirohardjo, Jakarta.

Sastrawinata, S., et al. 2005. IImu Kesehatan Reproduksi: Obstetri Patologi Edisi 2. Jakarta: EGC

Setiadi. 2007. Konsep dan Penelitian Riset Keperawatan. Edisi 1. Yogyakarta: Graha IImu

Soewondo.Kendal.http://eprintz.undip.ac.id/183421/ 1/ROZIKHAN.pdf. diperoleh 20 Desember

Sudhaberta, K. (2001). Penanganan Preeklampsia Berat dan Eklampsia. (Online)diunduh 28 Januari 2016. (Online) diunduh 01 April 2016. Available fromURL: HYPERLINK

Susanto.H. 2003. Obstetri Patologi, Fakultas Kedokteran Universitas Padjajaran,Bandung

Utomo, B, 2007, Tantangan Pencapaian Millenium Development Goals (MDG's) Bidang Kesehatan di Indonesia

WHO, 2007, Dibalik Angka, Pengkajian Kematian Maternal dan Komplikasi Untuk Mendapatkan Kehamilan Yang Lebih Aman, diterjemahkan dan diedit oleh $\mathrm{dr}$. George Andriaansz,SPOG 
WHO, 2006, Menggunakan Hak Asasi Manusia Untuk Kesehatan maternal danNeonatal, Laporan Analisa Uji Coba di Indonesia, bekerjasama dengan Depkes RI

Wibisono Bambang dr. Kematian Perinatal pada Preeklampsia - Eklampsia. FK. Undip Semarang, 1997:6-12.

Wiknjosastro,H, dkk, 2006, IImu Kebidanan, Yayasan Bina Pustaka Sarwono Prawirohardjo, Jakarta

www.Digized by USU Digital Library. (Pendarahan selama kehamilan, 2004) Searching 01 April 2016 www.ejournal.litbang.depkes.go.id/ di akses tanggal 01 April 2016)

www.kalbe.co.id/files/cdk/.../cdk_133_obstetri_dan ginekologi.Trijatmo Rachimhadhi.(2007), Preeklamsia dan Eklamsia,Jakarta:Yayasan BinaPustaka Sarwono Prawiroharjo.

http://www.depkes.jabarprov.go.id diakses pada tanggal 18-04-2016)

Zhang J, et.al, 1997, Epidemiology Of Pregnancy-Induced Hypertention, Epidemiologis Reviews 19 : 218-231 